\title{
WPS 3031
}

\section{Policy Research Working Paper 3031}

\section{Imports, Entry, and Competition Law as Market Disciplines}

\author{
Hiau Looi Kee
}

Bernard Hoekman

The World Bank

Development Research Group

Trade

April 2003

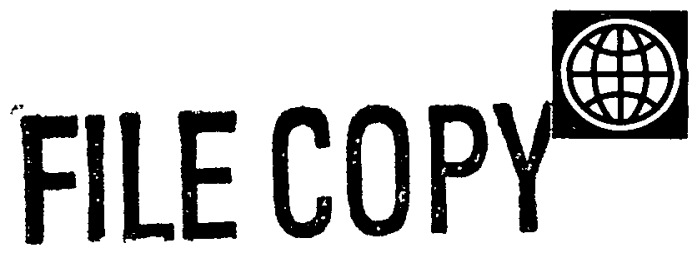




\section{Abstract}

Since the early 1990 s numerous countries have adopted or strengthened competition legislation. Kee and

Hoekman investigate the impact of competition law on industry markups over time and across a large number of countries. They find both domestic and foreign competition to be major sources of market discipline in concentrated markets, but that the direct effect of competition law is insignificant. However, once allowance is made for the endogeneity of both domestic competiton (number of firms) and the adoption of a competition law, the authors find that competition laws have an indirect effect on equilibrium markups by promoting a larger number of domestic firms.

This paper-a product of Trade, Development Research Group-is part of a larger effort in the group to study the links between trade and competıtıon policies. Copies of the paper are available free from the World Bank, $1818 \mathrm{H}$ Street NW, Washington, DC 20433. Please contact Paulına Flewitt, room MC3-333, telephone 202-473-2724, fax 202-522-1159, emal address pflewitt@worldbank.org. Policy Research Working Papers are also posted on the Web at http:// econ.worldbank.org. The authors may be contacted at hlkee@worldbank.org or bhoekman@worldbank.org. April 2003. (30 pages)

The Polcy Research Working Paper Sertes disseminates the findings of work in progress to encourage the exchange of ideas about development issues. An objective of the sertes is to get the fundings out quickly, even tf the presentations are less than fully polished. The papers carry the names of the authors and should be cated accordingly. The findings, interpretations, and conclusions expressed in this paper are entrely those of the autbors. They do not necessartly represent the view of the World Bank, tts Executwe Directors, or the countries they represent 


\title{
Imports, Entry and Competition Law as Market Disciplines ${ }^{1}$
}

\author{
Hiau Looi Kee ${ }^{2}$ and Bernard Hoekman ${ }^{3}$
}

JEL classification: F12, F13, L11, L44

Keywords: Competition law, import penetration, domestic entry, industry markup.

\footnotetext{
1 The authors thank Mary Amiti, Simon Evenett, Caroline Freund, Peter Holmes, Marcelo Olarreaga, Caglor Ozden and David Tarr for comments and feedback. The findings, interpretations and conclusions expressed in this paper are entirely those of the authors. They do not necessarily represent the view of the World Bank, its Executive Directors, or the countries they represent.

2 Development Economics Research Group, The World Bank, 1818 H Street N.W., Washington, DC 20433, USA. E-mail: hlkee@worldbank.org.

3 Development Research Group, the World Bank, 1818 H Street N.W., Washington, DC 20433, USA, and CEPR, London, UK. E-mail: bhoekman@worldbank.org.
} 



\section{Introduction}

An important focus of discussions in international fora such as the WTO and the OECD is whether and how to expand the reach of competition legislation across members, strengthen cooperation between national agencies and explore the scope for the adoption of common norms. For example, multilateral dialogue in the WTO is currently focusing on an agreement that members abide by 'core principles' - nondiscrimination, national treatment and transparency (due process) - as well as, possibly, provisions banning 'hard core' cartels (Hoekman and Mavroidis, 2003).

Relatively little cross-country empirical work has been done to identify the effect of competition law on the contestability of markets. For OECD countries this is an interesting research question, but not of major policy significance given that competition enforcement is long established in the main jurisdictions (US, EU, Canada, Japan). For these countries the policy questions revolve around issues such as the appropriate approach to dealing with vertical restraints and merger control. In many developing countries, however, the question is much more fundamental and centers on determining the magnitude of the net benefit of competition law. Adoption of such mechanisms is costly, requiring the allocation of skilled lawyers and economists that are in scarce supply. It may well be that a larger 'bang for the buck' can be obtained through less administratively costly policy measures to increase competition on markets. Of course, trade economists have long argued that trade liberalization is a powerful and administratively very simple way of enhancing competition (Bhagwati, 1968). Other economists have emphasized the importance of removing government created

4 It is often argued that an open trade regime is a powerful instrument to discipline the behavior of firms which have market power. The empirical literature investigating the impact of import competition on the pricing behavior of domestic firms has concluded that trade liberalization forces firms to set prices closer to marginal costs. That is, there is a negative relationship between price-cost margins (markups) and the openness of the economy. Indeed, Levinsohn (1993), Harrison (1994), Grether (1996) and Djankov and Hoekman (2000) all find some support for the hypothesis that imports are a source of market discipline in 
barriers to entry and exit for firms (Djankov et al, 2002).

This paper attempts to determine the relative impact of competition law on competition outcomes. Specifically, we investigate empirically the contribution of competition law relative to alternative types of policies that enhance the contestability of markets, in particular import competition and measures to ease entry and exit of firms. From a policy perspective this analysis is relevant both in terms of informing decision makers on the relative importance of alternative national mechanisms to promote competition, and in terms of identifying where the priority areas for action may lie in terms of international cooperation.

We develop a simple model where the markup by an industry of price over marginal cost is positively related to the size of domestic sales and negatively related to the number of domestic firms that are active in the industry, the magnitude of imports and the demand elasticity of the industry. Industry markups are estimated as a semi-translog function of the number of firms, value of imports and domestic production, using country, year and industry fixed effects to control for the demand elasticity of the industries. Having determined the impact of foreign and domestic competition (the number of domestic firms in an industry), a dummy variable approach is used to capture the impact of the introduction of a competition law.

The results of cross-industry, cross-country, time series regressions using a sample of 28 industries, 42 countries and 18 years indicate that controlling for import competition and the number of firms in each industry/country, competition law has no direct impact on industry markups. These results suggest that from a competition viewpoint, policy priority should be given to measures that directly increase competition on markets - such as trade liberalization or the removal of entry barriers. However, once we control for the endogeneity of competition studies of domestic firms behavior in Turkey, the Ivory Coast, Mexico, and Bulgaria respectively. For reviews of the literature, see Levinsohn (1996), Roberts and Tybout (1996) and Evenett, Lehmann, and Steil (2000). 
law adoption, we also find that industries that operate under a competition law tend to have a larger number of domestic firms, suggesting that in the long run, competition laws may have an indirect effect on domestic industry markups by promoting entry.

This paper is organized as follows. We discuss our empirical model in Section 2, and present the data set in Section 3. Section 4 shows the estimation results, and Section 5 concludes the paper with some policy discussions.

\section{Model}

One of the biggest difficulties in studying the effectiveness of competition law on industries is to define a measurable outcome variable. Given that the main objective of any competition law is to promote competition, variables that capture the level of competition, or the market power of firms in the industries are natural candidates. One such variable is the markup of price over marginal cost of production by firms in an industry. ${ }^{5} \quad$ In perfect competition, price equals marginal cost, so that the equilibrium markup equals one. When firms have some market power, so that price is greater than marginal cost, we observe markups that are greater than one in equilibrium. Thus, in principle, the markup of price over marginal cost provide a simple way to measure the level of competition. However, in practice, given that marginal cost is itself not a well measured variable, the use of markups as a measure of competition has been limited.

Hall (1988) developed a simple way to estimate industry markup from the production function of firms. Relaxing the neoclassical assumptions of perfect competition and constant returns to scale, Hall showed that by estimating the parameters of a production function, we can interpret the coefficient associated with the weighted growth rate of labor as the 5 Other such variables include total revenue over total cost (Roberts and Tybout, 1996) and entry threshold (Bresnahan and Reiss, 1991). 
implied equilibrium markup. Based on his model, Levinsohn (1993) and Harrison (1994) showed that trade liberalization is associated with lower industry markups in Turkey and Cote D'Ivoire, respectively. Subsequent papers by Norrbin (1993), Roeger (1995), and Basu and Fernald (1997) update Hall's approach to account for the usage of intermediate input and returns to scale. To address endogeneity issues of Hall regressions which are also common across most production function estimations, Olley and Pakes (1996) use a polynomial of capital and investment as a control for the unobserved productivity. They show that such a nonparametric correction is successful in reducing the upward bias on the labor coefficient, without using instrumental variables that may be questionable. This is the approach taken by this paper.

In addition, we incorporate an industry markup function, derived from a short-run symmetric Cournot equilibrium, into a Hall-type regression in this paper. In a short-run symmetric Cournot equilibrium (that is, not allowing for entry), industry markups depend on the number of domestic firms, the share of imports in the domestic market, and the magnitude of total domestic sales. By introducing the industry markup function into the Hall regression directly, we are able to interpret the estimated coefficients associated with the resulting interaction terms between these variables and the weighted growth rate of labor per capital as the marginal effects of these variables on industry markups. In other words, we are able to directly estimate the effects of domestic and foreign competition on industry markups without explicitly estimating the industry markups themselves. This allows us to avoid some econometric complications arising from the use of an estimated dependent variable, and at the same time improve the efficiency and degrees of freedom of the estimations.

In the empirical model developed below the role of competition law is twofold. In the short-run, given a fixed number of domestic firms and import penetration, the introduction 
of a competition law can be regarded as a structural change in the economy that may lower industry markups directly by shifting down the industry markup functions. However, in the long-run, when firms are free to enter and exit, a competition law may affect the number of domestic firms by enhancing the contestability of markets through facilitating entry (via enforcement of provisions regarding restrictive business practices, the abuse of dominant positions, the potential for creating such dominance through mergers, etc.). It is important to recognize that countries will have different incentives to adopt competition laws, depending on the competition environment that prevails in their industries. In the long-run, both the number of firms and the adoption of competition law is endogenous. This is taken into account in our estimations.

\subsection{Hall Regression}

For each country, let the output of industry $i$ in period $t$ be characterized by a production function of labor input, $L_{t t}$, and capital input, $K_{t t}$,

$$
Q_{i t}=A_{t t} F_{i}\left(L_{\imath t}, K_{i t}\right)
$$

Differentiating Equation (1) with respect to time and dividing both sides by $q_{t}$ yields the growth rate version of Equation $(1):^{6}$

$$
\begin{aligned}
& \hat{Q}_{\imath t}=\hat{A}_{\imath t}+\alpha_{i L} \hat{L}_{\imath t}+\alpha_{i K} \hat{K}_{i t}, \text { where } \\
& \alpha_{i L}=\frac{L_{\imath t}}{F_{z t}} \frac{\partial F_{i}}{\partial L_{\imath t}}, \text { and } \alpha_{i K}=\frac{K_{i t}}{F_{i t}} \frac{\partial F_{i}}{\partial K_{t t}}
\end{aligned}
$$

are the elasticity of output with respect to labor and capital inputs, respectively. ${ }^{7}$

$\checkmark$ Here we adopt the convention to denote the growth rate of a variable with -:

$$
\hat{X}_{t} \equiv \frac{\partial \ln X_{t}}{\partial t}=\frac{1}{X_{t}} \frac{\partial X_{t}}{\partial t}
$$


For each industry $i$, assume that the production function $F_{i}$ is homogeneous of degree $S_{i}$. $F_{z}$ shows increasing, constant, or decreasing returns to scale with respect to all inputs when $S_{\imath}$ is greater than, equal to, or less than unity. Subtracting the growth rate of the capital input from both sides of Equation (2) and applying Euler's theorem for homogeneous functions, we can re-express Equation (2) as: ${ }^{8}$

$$
\hat{q}_{i t}=\hat{A}_{\imath t}+\alpha_{\imath L} \hat{l}_{\imath t}+\left(S_{\imath}-1\right) \hat{K}_{\imath t}
$$

with the convention that $x=\frac{X}{K}$, (i.e., small caps express variables in per unit of capital terms).

Let

$$
\mu_{i t}=\frac{p_{t t}}{c_{i t}}
$$

be the price over marginal cost markup of industry $i$, and let $\theta_{\imath t L}$ be the share of labor in total revenue. Given that $\alpha_{\imath L}=\mu_{i t} \theta_{\imath t L}$, Equation (5) becomes

$$
\hat{q}_{i t}=\hat{A}_{\imath t}+\mu_{\imath t}\left(\theta_{\imath t L} \hat{l}_{i t}\right)+\left(S_{\imath}-1\right) \hat{K}_{\imath t}
$$

Equation (7) can form the basis for estimation of industry markups by regressing the growth rate of value added per unit of capital on the weighted growth rate of labor per unit of capital and the growth rate of capital. ${ }^{9}$

As suggested by Basu and Fernald (1995), one may be concerned regarding empirical analyses that use the growth rate of real value added instead of the growth rate of real output, given that due to the construction of value-added statistics, the growth rate of real value added will not be independent of the growth rate of intermediate inputs if the market is not perfectly competitive (even when production functions are weakly separable). However, the UNIDO industry level data set only provides real output for a few countries. Thus, due to data constraints, we have to rely on real value added data rather than real output data. 8 According to Euler's theorem, if a production $F_{2}\left(L_{2 t}, K_{i t}\right)$ is homogeneous of degree $S_{2}$ with respect to its inputs, then

$$
\alpha_{i}+\alpha_{2 K}=S_{i}
$$

J Note that while maintaining the assumption that $\alpha_{1} L$ and $\alpha_{i K}$ are parameters of the production function of industry $i$ that are constant over time, we allow industry markup, $\mu_{i t}$, and labor share, $\theta_{\imath t L}$ to vary. This is consistent with the empirical data, as we observe some fluctuation in $\theta_{i t L}$ from year to year. 
Complications arise when using Equation (7) due to the fact that productivity growth, $\hat{A}_{\imath t}$, is unobservable. It is crucial to control for $\hat{A}_{\imath t}$ since it enters the firm's first-order conditions for profit maximization that determine both input demand and output supply. Not controlling for $\hat{A}_{2 t}$ will bias upward the least squares estimates for the coefficients of the growth rate of labor per unit of capital and the growth rate of capital - a classical endogeneity problem.

Olley and Pakes (1996) develop an empirical strategy to control for the endogeneity problem. They introduce a polynomial of capital and investment as a control for the unobserved productivity. They assume that at the beginning of every period, firms know their productivity but this is not observable by the researcher. Based on the realized productivity, firms decide to stay in business or to exit. Providing that all surviving firms have positive investment, their investment can then be used as a control for productivity. ${ }^{10}$ In other words, Olley and Pakes assume that firms with higher investment are those that realize higher productivity growth. They show that by introducing a polynomial of investment and capital stock as a control for productivity in the estimation of the production function, the upward bias on the coefficient of labor input is reduced. ${ }^{11}$ Given that our analysis centers on industry markups (that is, the coefficient on labor input), getting consistent estimates of the labor coefficients is critical. We therefore adopt the Olley and Pakes correction and use a polynomial of capital and investment to control for the unobserved industry productivity growth.

10Levinsohn and Petrin $(1999,2000)$ show that instead of investment, intermediate input could be a good instrument for productivity growth, especially for those firms that stay in business but do not have positive investment every year.

11 Olley and Pakes (1996) also discuss bias on the capital coefficient due to entry and exit behavior of firms, and use a selection model to control for it. 


\subsection{Markup Function}

Leaving out time and industry subscripts for ease of exposition, assume that for each industry, domestic and foreign firms are Cournot players in the domestic market for a homogenous goods. Given homogeneity we assume further that there is a world market for the good and that imports can be characterized as being provided by one importing foreign firm, with a share in the domestic market of $m$. There are $N$ identical domestic firms. Domestic firms face a positive fixed cost of entry, $F$, associated with government imposed entry and/or exit regulations of the type documented by Djankov et al (2002). Taking the quantity produced by other firms, $Q_{-n}$, as given, each domestic firm $n$ chooses its output by maximizing its profits:

$$
\pi_{n}^{*}(N, F, m) \equiv \max _{Q_{n}}\left\{\pi_{n}\left(Q_{n}, Q_{-n}\right)=p(Q) Q_{n}-c\left(Q_{n}\right)-F\right\}, \forall n=1, \ldots, N
$$

where $p(Q)$ is the inverse demand function, $Q=Q_{D}+Q_{M}=\sum_{n=1}^{N} Q_{n}+Q_{M}, Q_{D}$ is total domestic production (sales), and $Q_{M}$ is the import quantity. (For simplicity, throughout what follows we assume that domestic firms do not export, so that domestic production equals domestic sales. In the empirical analysis below we take into account exports by domestic firms in the calculation of import market shares.) The first order condition for profit maximization implies:

$$
p(Q)\left[1-\frac{1}{\varepsilon} \frac{Q_{n}}{Q}\right]=c^{\prime}\left(Q_{n}\right)
$$

where $\varepsilon \equiv-(\partial Q / \partial p)(p / Q) \geq 0$ is the price elasticity of demand.

In a symmetric Cournot equilibrium, total domestic production is given by $Q_{D}^{*}=N Q_{n}^{*}$. Rearranging Equation (8) according to the definition of the markup in Equation (6) yields

$$
\mu^{*}=\frac{1}{1-\frac{1}{\varepsilon} \frac{1}{N}\left(\frac{Q_{D}^{*}}{Q_{D}^{a}+Q_{M}^{a}}\right)} .
$$


Thus, the equilibrium markup in the domestic industry is inversely related to the magnitude of imports and the number of firms, while it is positively related to size of domestic production. $^{12}$ In addition; given the homogenous good assumption, the equilibrium price set by the domestic firms and the importer is identical, which means that the quantity ratio equals the volume ratio:

$$
\frac{Q_{D}^{*}}{Q_{D}^{*}+Q_{M}^{*}}=\frac{p^{*} Q_{D}^{*}}{p^{*} Q_{D}^{*}+p^{*} Q_{M}^{*}}=\frac{1}{1+m}
$$

where $m=\frac{p^{*} Q_{M}^{*}}{p^{*} Q_{D}^{*}}$ denotes the ratio of imports to domestic sales of the industry. Thus, given a fixed demand elasticity, industry markups are lower when there are more domestic firms and when the ratio of imports to domestic sales is larger:

$$
\mu^{*}(\varepsilon, N, m)=\frac{1}{1-\frac{1}{\varepsilon} \frac{1}{N} \frac{1}{1+m}}
$$

How effective are domestic and import competition in reducing industry markup, given the industry demand elasticity? Figure 1 plots industry markup against number of firms, given a hypothetical demand elasticity of 2 and an import ratio of 0.3 . When there is only one domestic firm, the industry markup is about 1.6. The markup falls rapidly as the number of domestic firms increases, falling below 1.1 once there are more than 5 firms in the industry. With 30 firms or more, entry by an additional firm has only a negligible impact on the industry markup.

Similarly, Figure 2 plots industry markup against the ratio of imports to domestic sales, given a hypothetical demand elasticity of 2 and 10 firms in the industry. We again observe that imports reduce industry markups at a declining rate. Moving from zero imports to an import volume that equals sales by domestic firms, markups drop from 1.05 to 1.025 . The markup of the industry drops below 1.1 once imports are more than 4 times the value of total domestic sales.

12See Jacquemin (1982) for a similar derivation. 
Figure 1: Industry Markup vs. Number of Firms $(\varepsilon=2 \& m=0.3)$

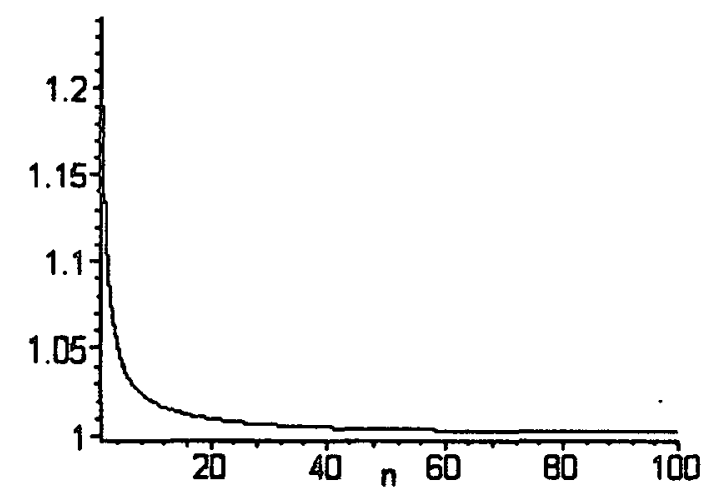

Figure 2: Industry Markup vs. Imports $(\varepsilon=2 \& N=10)$

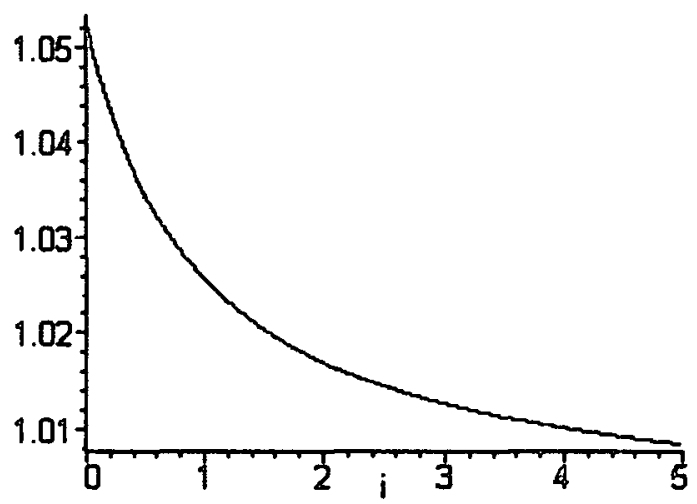


Figure 3 plots industry markup against the ratio of imports to domestic sales and the number of domestic firms, given a hypothetical demand elasticity of 2 . Figure 3 clearly illustrates how import competition can act as a substitute for domestic competition when there are a limited number of domestic firms in the industry.

Figure 3: Industry Markup vs. Number of Firms and Imports $(\varepsilon=2)$

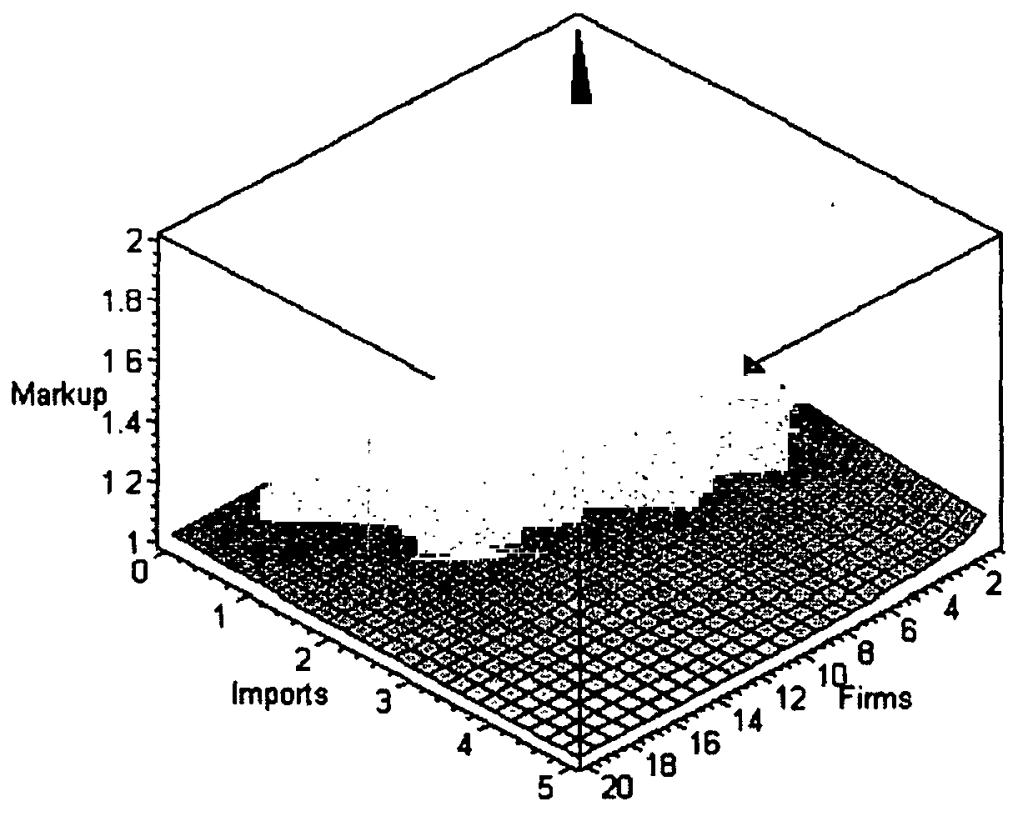

Summing up, both domestic and import competition have larger effects on industry markup when the existing industry markup is higher, as can be expected in highly concentrated markets. If an existing industry is already near perfect competition, additional domestic firms (entry) or imports would have only minimal impact on markups. These findings are consistent with those of Bresnahan and Reiss (1991), where markets are shown to approximate a competitive one when there are 5 or more firms. 
Equation (9) implies that industry markup is a non-linear function of the number of domestic firms and the share of imports in domestic sales. We therefore approximate the non-linear relationship with a second order semi-translog function:

$$
\begin{aligned}
\mu_{i t c}^{*}(N, m ; \mathbf{Z})= & \beta+\beta_{c}+\beta_{t}+\beta_{i}+\beta_{N N}\left(\ln N_{t t c}\right)^{2}+\beta_{N} \ln N_{i t c} \\
& +\beta_{M M}\left(\ln m_{i t c}\right)^{2}+\beta_{M} \ln m_{t t c}+\beta_{N M} \ln N_{i t c} \ln m_{i t c}+g(\mathbb{Z}),
\end{aligned}
$$

where the demand elasticity of industry $i$ in period $t$ of country $c$ is assumed to be the sum of country, time and industry fixed effects and matrix $\mathbb{Z}$ represents a set of controls which may help reduce the bias of the estimated coefficients. Variables in $\mathbf{Z}$ include the total value of domestic output and labor cost in each industry, GDP and GDP per capita of the economy.

\subsection{Short-Run Empirical Model}

We incorporate the industry markup function into the Hall regression by substituting Equation (10) into Equation (7) :

$$
\begin{aligned}
\hat{q}_{i t c}= & C_{c}+C_{\imath}+C_{t}+P^{5}\left(\hat{K}_{t t c}, \hat{I}_{i t c}\right)+\left[\beta+\beta_{c}+\beta_{t}+\beta_{i}+\beta_{N N}\left(\ln N_{i t c}\right)^{2}+\beta_{N} \ln N_{t t c}\right. \\
& \left.+\beta_{M M}\left(\ln m_{i t c}\right)^{2}+\beta_{M} \ln m_{\imath t c}+\beta_{N M} \ln N_{i t c} \ln m_{\imath t c}+g(\mathbb{Z})\right]\left(\theta_{i t L} \hat{l}_{z t}\right)
\end{aligned}
$$

where $P^{5}\left(\hat{K}_{i t c}, \hat{I}_{z t c}\right)$ denotes the 5 th order polynomial of capital and investment, and to gether with country-industry fixed effects and year fixed effects, are the controls for industry productivity growth.

Equation (11) shows that the coefficients of the interaction terms between the arguments of the semi-translog function and the weighted growth rate of labor, $\theta_{t t L} \hat{l}_{i t}$, can be interpreted as the marginal effects of those factors on industry markups. For example, the effect of a one percent increase in import penetration on industry markup and the effect of a one percent 
increase in the number of domestic firms on industry markup would be respectively

$\frac{\partial \mu_{i t c}^{*}(N, m ; \mathbf{Z})}{\partial \ln m_{\imath t c}}=\frac{\partial\left(\partial \hat{q}_{i t c} / \partial \theta_{i t L} \hat{l}_{i t}\right)}{\partial \ln m_{i t c}}=\frac{\partial^{2} \hat{q}_{t t c}}{\partial \theta_{i t L} \hat{l}_{\imath t} \partial \ln m_{\imath t c}}=\beta_{M}+2 \beta_{M M} \ln m_{z t c}+\beta_{N M} \ln N_{\imath t c}$, $\frac{\partial \mu_{t t c}^{*}(N, m ; \mathbf{Z})}{\partial \ln N_{t t c}}=\frac{\partial\left(\partial \hat{q}_{\imath t c} / \partial \theta_{i t L} \hat{l}_{\imath t}\right)}{\partial \ln N_{t t c}}=\frac{\partial^{2} \hat{q}_{i t c}}{\partial \theta_{i t L} \hat{l}_{z t} \partial \ln N_{\imath t c}}=\beta_{N}+2 \beta_{N N} \ln N_{z t c}+\beta_{N M} \ln m_{\imath t c}$.

Thus, assuming that our application of the Olley and Pakes (1996) methodology is successful in correcting for the endogeneity of the regression errors, and that the current value of imports and number of firms are exogenous, the estimated coefficients of the interaction terms will be unbiased estimates of the effects of import penetration and domestic entry on industry markups. The theoretical model is considered to be not rejected by the data if the estimated values of both $\beta_{M}$ and $\beta_{N}$ are negative, while $\beta_{M M}, \beta_{N N}$, and $\beta_{N M}$ are positive.

Finally, it is clear that even in the short-run, import penetration is likely to be endogenous. When there is a positive productivity shock or a favorable endowment shock, output of the industry may increase and reduce the import demand of that industry, given a fixed consumption pattern. While we already use the 5th degree polynomial of capital and investment to control for industry specific productivity shock, we have yet to control for endowment shocks. Following Trefler (1993) and Goldberg and Maggi (1999), we model the import penetration ratio as a function of factor shares in each industry/country, in addition to all the exogenous variables of the model $(\mathbf{W})$ :

$$
\ln m_{\mathrm{atc}}=\delta+\delta_{c}+\delta_{t}+\delta_{i}+\delta_{f c} \text { factor_share } \text { ftc }_{c}+h(\mathbf{W})
$$

Together, Equations (11) and (12) form a system of two equations to be simultaneously estimated to determine the short-run effects of imports and domestic competition (number of firms) on the level of industry markups.

Given this framework, we then consider the introduction of a competition law as a structural change to the economy, one that is expected to enhance competition between domestic 
firms and reduce industry markups without specifying the channel. To test for whether competition law has this effect, we introduce a dummy variable, $D_{t c}$, in the markup equation, $\mu_{z t c}^{*}(N, m ; Z)$, which equals one if there is a competition law in the country in a given year. In other words, we run the following system of panel regressions:

$$
\begin{aligned}
\hat{q}_{i t c}= & C_{c}+C_{i}+C_{t}+P^{5}\left(\hat{K}_{i t c}, \hat{I}_{i t c}\right)+\left[\beta_{D} D_{t c}+\beta+\beta_{c}+\beta_{t}+\beta_{i}+\beta_{N N}\left(\ln N_{t t c}\right)^{2}\right. \\
& +\beta_{N} \ln N_{t t c}+\beta_{M M}\left(\ln m_{i t c}\right)^{2}+\beta_{M} \ln m_{\imath t c}+\beta_{N M} \ln N_{\imath t c} \ln m_{i t c} \\
& +g(\mathbf{Z})]\left(\theta_{i t L} \hat{l}_{i t}\right) \\
\ln m_{\imath t c}= & \delta+\delta_{c}+\delta_{t}+\delta_{\imath}+\delta_{f c} \text { factor_share }{ }_{i t c}+h(\mathrm{~W}) .
\end{aligned}
$$

If the introduction of competition law has an effect on industry markup, we would expect the coefficients of the competition law dummy to be negative and statistically significant.

\subsection{Long-Run Equilibrium and the Role of Competition Laws}

In the short-run, it is reasonable to assume that the number of firms is fixed, and thus is exogenous to, among other variables, the industry markups and the policy environment. However, in the longer run, the number of firms is endogenous, a function of the profitability of the industry as well as the ease of entry. We capture the latter by a fixed cost, $F$ in the model. Specifically, given a fixed cost of entry and the prevailing import share, the equilibrium number of firms is determined by the condition that the profit obtained by an additional firm is smaller than the fixed cost of entry:

$$
N^{*}(F, m)=\arg \max \left\{0, \pi^{*}(N, F, m)\right\}
$$

As the number of domestic firms is a discrete variable, in equilibrium it is possible for all of the $N^{*}$ existing firms to make a (small) positive profit. 
A major role of competition law is to enhance the contestability of markets. Competition laws may affect the number of domestic firms in the long run by prohibiting anti-competitive behavior that raises entry costs. This suggests that the existence of a competition law should, ceteris paribus, lead to a higher number of domestic firms. To the extent that the number of domestic firms affects industry markup, competition law would then indirectly affect markups. ${ }^{13}$

On the other hand, in the long-run (that is, allowing for entry and exit), there may also be a country 'self-selection' effect in that the adoption of competition law is a function of the overall level of competition prevailing in an economy. Specifically, if the industry import penetration ratio is high, or there is a large enough number of domestic firms in each industry, the need to establish a competition law is less, controlling for the stage of development and size of the countries. Conversely, if there is a small number of domestic firms, it may be politically more difficult for countries to set up a competition law as the incentive for firms to lobby against such a law will be higher. Overall, the impact of domestic market structure on the probability for countries to adopt a competition law is therefore an empirical question. Both entry and the decision by governments to adopt competition laws are endogenous in the long-run.

Estimating the long-run effect of competition law on domestic industry markup via its effects on the number of domestic firms thus requires estimation of a self-selection model, where domestic entry depends in part on the existence of competition law, conditioned on countries developing a competition law. Specifically, we test the following two-step model 1.W We recognize that in practice the enforcement of competition law may be such as to raise the costs of entry for new efficient entrants. This type of capture of competition enforcement by incumbents, as well as enforcement mistakes that conclude that active price competition is predatory, would lead to an opposite conclusion. The empirical analysis that follows can be seen as providing a test of the hypothesized effect of competition law on the number of firms in an industry. 
for the long-run equilibrium:

$$
\begin{aligned}
\ln N_{i t+1 c} & =\gamma_{D} D_{t c}+\gamma_{\lambda} \lambda_{t c}+f(\mathbb{X}) \\
D_{t c} & =\left\{\begin{array}{c}
0 \text { if } D\left(\bar{N}_{t c}, \bar{m}_{t c} ; \omega\right) \leq 0 \\
1 \text { if } D\left(\bar{N}_{t c}, \bar{m}_{t c} ; \omega\right)>0
\end{array}\right.
\end{aligned}
$$

where $\lambda_{t c}$ is the estimated hazard rate of the country adopting a competition law in year $t$, based on the first step selection model which specifies the decision rules of the government. Without controlling for $\lambda$, the estimated treatment effect of adopting a competition law, $\gamma_{D}$, is likely to be biased and inconsistent. Note that the dependent variable of the second step regression, Equation (15), is the one period lead value of the number of domestic firms. This captures the effect of a competition law on domestic entry, since in the short-run, entryrelated fixed costs are likely to keep the current period number of firms constant. On the other hand, Equation (16) specifies the decision making process of the government, which depends on the average industry characteristics, such as the current number of firms and import penetration. Both $\mathrm{X}$ and $\boldsymbol{\omega}$ are the matrix of control variables in the two-step model.

\section{Data}

Our data set comprises 28 industries in 42 developed and developing countries for 18 years (1981-1998). Industries are defined at the 3 digit level of the International Standard Industrial Classification (ISIC). The total number of observations in the data set is only 11,484 , due to missing values for either industries, countries or years. Industry level production and trade data (exports and imports) are obtained from UNIDO and the Trade and Production Database compiled by Nicita and Olarreaga (2002). ${ }^{14}$ We utilize World Bank (2002) for country level data on variables such as GDP and GDP per capita. Information on the existence and year of adoption of competition legislation is drawn from national sources and 14 As noted earlier, we use export data to calculate import shares in total sales. 
the OECD. Table 1 reports sample averages of the key variables used in the regressions by country.

Countries and industries in our data set vary quite significantly. On average, each industry in each country has some 1,500 firms, ranging from less than 50 firms on average in each industry in Panama to more than 15,000 firms on average in a Japanese industry. The size of industries also varies substantially across countries - with average sales of US\$70 million, Cyprus has the smallest average industry size, while at nearly US $\$ 90$ billion, industries in the U.S. are the largest.

Import competition is weakest in Japan, where the ratio of imports to domestic production for a typical industry is only 6 percent, compared to 80 percent for a typical industry in Hong Kong. On average, the ratio of imports to domestic output is around 18 percent in the sample. In terms of the year in which competition law was first passed, Canada and U.S. have long-standing enforcement dating back to the turn of last century, while Egypt, Hong Kong and Singapore have yet to adopt any form of competition law. Nineteen countries in the data set had a competition law prior to 1981. A number of developing and transitional economies subsequently adopted competition laws during the sample period.

Table 1 also presents data on GDP and GDP per capita for the countries in the data set. Here again there is substantial variation. The largest country in the sample, the U.S., is more than 1000 times larger than Jordan, the smallest country in the sample. On the other hand, the richest country in the sample is Japan, with a per capita GDP more than 100 times greater than the poorest countries (India and Kenya).

Table 2 provides sample averages of the main variables used by industry. The food industry has the largest average number of firms, with an average of more than 5200 firms in each country. On the other hand, with an average of only 33 firms, the petroleum refining 
industry is the most concentrated. The largest industry in the sample is the transport equipment industry, with average sales of more than US\$20 billion. The pottery and earthware industry lies at the other end of the spectrum with average sales of only US $\$ 550$ million per year. Firms in the petroleum industry on average are the largest in size - the typical firm has average sales of US $\$ 275$ million a year. On the other hand, the footloose apparel industry has the smallest average firm size - only about US\$1 million on average.

In terms of total volume of imports (trade), machinery and transport equipment industries rank first. However, judging by the ratio of imports to domestic production, leather products, scientific instruments and miscellaneous manufactures face the most intense import competition. With an import ratio of only 4 percent, the printing and publishing industry faces the least import competition.

Given the heterogeneity of the countries and industries in the data set, it is clearly important to control for country and industry specific effects in the estimation of the industry markup function. We also include year specific effects to control for any general movement of international prices and development trends.

\section{Results}

Table 3 presents the regression results for the short-run case, where the number of domestic firms is assumed to be fixed. The dependent variable is the growth rate of real industry value added relative to the capital stock, $\hat{q}_{\text {itc }}$. The top part of Table 3 presents the estimated semi-translog function, $\mu_{i t c}^{*}\left(\varepsilon_{i t c}, N_{i t c}, m_{i t c}\right)$, as defined in Equation (10).

Column (1) shows the baseline ordinary least squares regression using the full sample, without a competition law dummy variable. The estimated first order effect of imports on industry markup is negative and significant; the same holds for the estimated coefficient on 
domestic sales. The second order effects of these variables do not seem to matter in the full sample. On the other hand, we do not find the effect of the number of domestic firms on industry markups to be significant. This is not surprising, as in the full sample the average number of firms per industry is around 1,500. Thus, an additional firm in an industry should not have any significant effect. As shown in Figure 1 and Bresnahan and Reiss (1991), entry by new firms should have the greatest effects on competition when the existing market is highly concentrated. We will come back to this point later.

The lower part of Table 3 reports the variables that pertain to the industry production function, including a-5th order polynomial of capital and investment to control of industry productivity growth and a full set of industry, year and country fixed effects. The estimated coefficients are not reported due to space limitations, but are available upon request.

The competition law dummy variable representing the structural change due to the adoption of a competition law is introduced in Column (2). Not only is the dummy variable not significant, it is clear that adding the competition dummy does not change the previous result. In other words, we do not observe a significant effect of the competition law dummy variable on industry markups in the full sample - the primary policy-determined variable is foreign competition.

Given that the impact of both foreign and domestic competition on markups is most likely to be important in concentrated markets, the next two columns of Table 3 report the results of a three-stage least squares regression for a subset of industries with high concentration, specifically, those with no more than 30 domestic firms. Both the production and import penetration functions are simultaneously estimated. Column (3) reports the results of the production function estimation, and Column (3') reports those for the import penetration function. 
Column (3) indicates that for this sub-sample both imports and the number of domestic firms have a statistically significant effect in reducing industry markups. In fact, the marginal effect of a 10 percent increase in the import share in domestic sales is quantitatively equivalent to the marginal effect of an additional domestic entrant when there are only 9 firms in the market. In other words, the regression results suggest that both foreign and domestic competition are important in reducing domestic market power. Domestic sales and labor costs are also significant determinants of industry markups - a larger domestic market or lower cost of production are associated with higher industry markups.

Column (3') reveals that it is important to control for the endogeneity of import penetration (Equation (14) above). Factors that are negatively correlated with import penetration include the number of domestic firms and their sales, and the size of the overall economy. The effects of domestic endowments, proxied by the industry factor shares are also included in the regression, but coefficient estimates are not reported in the Table due to space limitations.

The effects of adding the competition law dummy to the system of equations are reported in column (4). Once again, we find that after controlling for the effects of domestic and foreign competition, the direct effect of competition law is not statistically significant, although it has the right sign, even if the analysis is restricted to more concentrated industries with less than 30 firms.

Table 4 presents results for the long-run equilibrium case, where both competition law and the entry and exit of domestic firms are endogenous. The number of domestic firms in an industry is responsive to, among other factors, the (fixed) cost of entry, which in turn is affected by the competition law of the countries. On the other hand, the government's decision to adopt a competition law may depend on the average level of competition in domestic industries, as well as the stage of development of the economy (proxied by GDP and 
GDP per capita). This suggests that the 'treatment effect' of competition law on domestic competition could be underestimated if we do not control for the self-selection bias. ${ }^{15}$

To correct for the endogeneity of competition law, we use a two-step procedure developed by Heckman (1979). Specifically, assume that for any period, a country's decision to adopt or abandon a competition law depends on the perceived level of industry markups, which are affected by the current level of imports, total domestic output, and total number of firms in the industry. We then first estimate a selection model by regressing the competition law dummy on average industry imports, domestic sales, and the number of firms, controlling for level of GDP and GDP per capita of the countries (Equation (16) above). We use the predict probability to construct the hazard rate, $\lambda_{t c}$, which will then be included in our entry regression (Equation (15)). We expect the estimated hazard rate to be negatively correlated with domestic entry, since the larger the number of domestic firms, the less likely the government would need to adopt a competition law to promote entry. Once the selfselection bias is controlled for by the estimated hazard rate, we expect the competition law dummy variable to have a positive effect in promoting entry (that is, the future $(t+1)$ number of firms in each industry).

Table 4 presents the results of the two-step selection model, where Column (1) shows the estimated effects of competition law and the self-selection bias on domestic entry, and Column (2) shows the estimated decision rule of governments in adopting competition laws.

The regression results suggest self-selection bias is indeed important. Correcting for this bias, industries operating under a competition law tend to have a larger number of domestic iSpecifically, while some countries may choose to pass and keep a competition law as a response to current high industry markups, others may not need such a law given low industry markups. This would lead to a contemporaneous positive correlation between industry markup and the status of the competition law. Not controlling for such a self-selection bias will lead to under-estimation of the effectiveness of competition law in reducing industry markups. In other words, given that we expect the treatment effect of competition law on industry markup to be negative, the least squares estimate would have an upward bias; if the bias is large enough it could result in a positive estimate. 
firms - on average 7.2 percent more. Moreover, countries' decisions to adopt competition laws do appear to be associated with variables that reflect the average level of competition in industries. For example, countries that have a higher level of import penetration are less likely to adopt competition laws, while countries that have a higher level of domestic sales in a typical industry are more likely to adopt competition laws.

The results in Tables 3 and 4 together suggest that while competition law may not have a direct effect on industry markups, even in more concentrated markets, it may affect industry markups in the long run via its effects on domestic entry and thus the long run equilibrium number of domestic firms.

\section{Conclusion}

For competition law to be a priority, it must yield a higher pay-off in terms of fostering competition than other policy options. The analysis in this paper suggests that dealing with trade barriers and government regulation that restrict domestic competition by impeding entry and exit by firms will generate a higher rate of return than the adoption of a competition law. Indeed, the regression results obtained here suggest that the direct effect of competition law on industry markup is not significant, even if the analysis is limited to the sub-sample of more concentrated industries. However, once account is taken of the endogeneity of competition law adoption, we find that competition laws have an effect on entry by domestic firms, which may indirectly affect the long run level of industry competition (markups). ${ }^{16}$

Any assessment of whether and how to adopt antitrust disciplines must of course consider factors that have been ignored in this paper. One such factor relates to the costs of 10Some authors have found that competition policy paradoxically reduces the number of firms-see e.g., Bittlingmayer (1985)-because prohibitions on price fixing and similar arrangements among firms encourage mergers. Our cross-country results suggest that while such incentives may exist the overall effect is the opposite. 
enforcement. Import liberalization not only has a more powerful and direct effect on competition, it also is a lower cost policy alternative, especially in the long run given no recurrent administrative enforcement and compliance costs. Another factor not considered here are possible international externalities associated with the enforcement (or non-enforcement) of antitrust by foreign countries. It must also be recognized that the analysis has been limited to industries producing tradable goods. Many products are non-tradable (e.g., many services). Even if tradable, competition may be limited to local markets for other reasons (e.g., transport costs). Certain products may be produced by (natural) monopolies or by firms where 'unnatural' (government-made) barriers to entry restrict contestability. In determining whether to make the adoption and enforcement of competition law a domestic priority, a wider focus will be required. However, it should also be recognized that in many cases competition law may not be the appropriate instrument to deal with such issues either. For example, in the case of services it may well be the case that the impact of government policies that restrict competition in services dominate (or are a major element allowing) private restrictive business practices. 


\section{RREIERTENCES}

Basu, Susanto, and John G. Fernald (1997), "Returns to Scale in U.S. Production: Estimates and Implications," Journal of Political Economy 105, no. 2, 249-283.

Bittlingmayer, George (1985), "Did Antitrust Policy Cause the Great Merger Wave?" Journal of Law and Economics 28, 77-118.

Bresnahan, Timothy F., and Peter C. Reiss (1991), "Entry and Competition in Concentrated Markets," Journal of Political Economy 99, no. 5, 977-1009.

Bhagwati, Jagdish N. (1968), The Theory and Practice of Commercial Policy. Princeton, N.J.: Princeton University Press.

Djankov, Simeon, and Bernard Hoekman (2000), "Market Disciplines and Corporate Efficiency: Evidence from Bulgaria" Canadian Journal of Economics, 33, 190-212.

Djankov, Simeon, Rafael La Porta, Florencio Lopez-de-Silanes, and Andrei Shleifer (2002), "The regulation of entry", Quarterly Journal of Economics.

Evenett, Simon, Alexander Lehmann, and Benn Steil (2000), Antitrust policy in an evolving global marketplace, Brookings Institution Press, Washington, DC.

Grether, J. (1996) "Mexico, 1985-1990: Trade Liberalization, Market Structure, and Manufacturing Performance," in M. Roberts and J. Tybout (eds.), Industrial Evolution in Developing Countries, Oxford: Oxford University Press.

Goldberg, Pinelopi K., and Giovanni Maggi (1999), "Protection for Sale: An Empirical Investigation," American Economic Revrew 89, no. 5, 1135-1155.

Hall, Robert E. (1988), "The Relation between Price and Marginal cost in U.S. Industry." Journal of Political Economy, vol. 96, no. 5, p. 921-947.

Harrison, Ann E. (1994), "Productivity, Imperfect Competition and Trade Reform: Theory and Evidence," Journal of International Economics, vol. 36, p. 53-73.

Heckman, James J. (1979), "Sample Selection Bias as a Specification Error," Econometrica, vol. 47, no. 1, 153-161.

Hoekman, Bernard, and Petros Mavroidis (2003), "Economic Development, Competition Policy and the WTO", Journal of World Trade, February.

Hoekman, Bernard, Hiau Looi Kee, and Marcelo Olarreaga (2001), "Markups, Entry Regulation and Trade: Does Country Size Matter?," Policy Research Working Paper. 2662, The World Bank.

Levinsohn, James (1993), "Testing the imports-as-market-discipline hypothesis", Journal of International Economics 35, 1-22.

Levinsohn, James (1996), "Competition policy and international trade policy", in J. Bhagwati and R. Hudec, eds. Fair Trade and Harmonization: prerequisites for free trade?, MIT Press, Boston. 
Levinsohn, James, and Amil Petrin (1999). 'When Industries Become More Productive, Do Firms? Investigating Productivity Dynamics." NBER Working Paper, no. 6893.

Levinsohn, James, and Amil Petrin (2000). "Estimating Production Functions Using Inputs to Control for Unobservables." NBER Working Paper, no. 7819.

Nicita, Allessandro, and Marcelo Olarreaga (2002), "Trade and Production, 1976-99," in B. Hoekman, A. Mattoo and P. English (eds.), Development, Trade and the WTO: A Handbook, World Bank.

Norrbin, Stefan C (1993), "The Relationship between Price and Marginal Cost in US Industries: A Contradiction," Journal of Polvtical Economy 101, no. 6, 1149-1164.

Olley, G. Steven, and Ariel Pakes (1996). "The Dynamics of Productivity in the Telecommunications Equipment Industry." Econometrica, vol. 64, no. 6, p. 1263-1297.

Roberts, Mark, and James Tybout (1996), Industrial evolution in developing countries, Oxford University Press.

Roeger, Werner (1995). "Can Imperfect Competition Explain the Difference between Primal and Dual Productivity Measures? Estimates for U.S. Manufacturing." Journal of Political Economy 103, no. 2, 316-330.

World Bank (2002), World Development Indicators. 
Table 1: Data at a Glance by Country, 1981-1998

\begin{tabular}{|c|c|c|c|c|c|c|c|c|c|c|c|}
\hline \multirow[b]{2}{*}{ Country } & \multicolumn{2}{|c|}{ Numbers of } & \multicolumn{3}{|c|}{ Value in Million of US\$ } & \multirow{2}{*}{$\begin{array}{c}\text { US\$ } \\
\text { GDPPC }\end{array}$} & \multirow{2}{*}{$\begin{array}{l}\text { Comp. Law } \\
\text { Passed in } \\
\end{array}$} & \multicolumn{4}{|c|}{ Growth Rates (\%) of } \\
\hline & Sample' & Firms & Imports & $\begin{array}{c}\text { Domestic } \\
\text { Production }\end{array}$ & GDP & & & $\mathbf{Y} / \mathbf{K}$ & $\mathbf{L} \mathbf{K}$ & $\mathbf{K}$ & $I$ \\
\hline Australia & 138 & 1008 & 742 & 2830 & 248000 & 16146 & 1906 & -0.34 & -1.28 & 0.41 & -1.09 \\
\hline Austria & 392 & 313 & 1120 & 2380 & 195300 & 25362 & 1951 & -1.88 & -2.67 & 3.19 & -0.02 \\
\hline Bulgaria & 60 & 577 & 86.9 & 286 & 12570 & 1485 & 1991 & -47.46 & -19.31 & 44.69 & 57.70 \\
\hline Canada & 276 & 1325 & 2660 & 8260 & 468100 & 17841 & 1889 & -2.93 & -2.50 & 4.56 & 2.70 \\
\hline Chile & 376 & 55 & 265 & 839 & 42260 & 3180 & 1959 & -1.02 & -1.53 & 6.91 & 6.20 \\
\hline Colombia & 402 & 271 & 213 & 798 & 69710 & 2050 & 1959 & -0.59 & -0.63 & 3.92 & -3.31 \\
\hline Cyprus & 335 & 278 & 74.2 & 70 & 6049 & 8978 & 1989 & -4.01 & -2.20 & 6.56 & -2.46 \\
\hline Denmark & 297 & 381 & 707 & 1300 & 150000 & 29267 & 1937 & -0.31 & -0.61 & 2.22 & 3.08 \\
\hline Egypt & 366 & 268 & 268 & 786 & 45400 & 907 & No Law & 4.12 & -0.34 & 3.85 & 5.13 \\
\hline Finland & 454 & 337 & 577 & 2020 & 116500 & 23419 & 1958 & -0.96 & -1.93 & 1.69 & 1.80 \\
\hline Greece & 336 & 294 & 407 & 797 & 102200 & 10210 & 1977 & 1.35 & -0.69 & -0.08 & -3.69 \\
\hline Hong Kong & 350 & 2042 & 6660 & 1610 & 106700 & 18265 & No Law & -8.99 & -6.23 & 4.58 & -10.30 \\
\hline Hungary & 351 & 199 & 27.5 & 876 & 48150 & 4588 & 1990 & -3.23 & -2.23 & 0.19 & -3.38 \\
\hline India & 462 & 3846 & 553 & 4410 & 271600 & 320 & 1969 & -5.36 & -4.53 & 12.66 & 8.78 \\
\hline Indonesia & 365 & 570 & 626 & 1430 & 129600 & 737 & 1999 & -6.28 & -3.47 & 23.83 & 15.18 \\
\hline Ireland & 257 & 194 & 412 & 801 & 40790 & 11605 & 1991 & -2.05 & -2.62 & 2.43 & -0.37 \\
\hline Italy & 330 & 1266 & 3820 & 13300 & 959700 & 16919 & 1990 & -4.86 & -3.37 & 5.34 & 1.03 \\
\hline Japan & 471 & 15044 & 4830 & 73500 & 4452000 & 36206 & 1947 & -1.37 & -1.27 & 2.85 & 2.90 \\
\hline Jordan & 325 & 424 & 99.7 & 109 & 5339 & 1603 & 2000 & 1.19 & -0.51 & 6.29 & -7.59 \\
\hline Kenya & 91 & 198 & 97.7 & 480 & 9283 & 333 & 1988 & -41.42 & -19.26 & 43.90 & 16.96 \\
\hline Korea & 494 & 2397 & 1930 & 8490 & 333900 & 7704 & 1980 & -1.89 & -2.81 & 9.96 & 8.27 \\
\hline Mexico & 252 & 111 & 679 & 1870 & 246900 & 3180 & 1992 & -4.06 & -1.95 & 8.35 & 1.01 \\
\hline Morocco & 209 & 282 & 217 & 586 & 34130 & 1317 & 1999 & 0.29 & -0.56 & 4.50 & 3.10 \\
\hline Netherlands & 208 & 327 & 3420 & 5150 & 340700 & 22943 & 1957 & -1.59 & -2.96 & 3.99 & 4.59 \\
\hline New Zealand & 80 & 843 & 385 & 974 & 51500 & 15370 & 1986 & -5.14 & -3.03 & 0.36 & -14.09 \\
\hline Norway & 433 & 283 & 761 & 1530 & 122200 & 28823 & 1926 & 2.34 & -1.11 & -0.01 & -1.14 \\
\hline Pakistan & 82 & 163 & 183 & 421 & 39590 & 402 & 1970 & -25.27 & -8.38 & 36.04 & -8.25 \\
\hline Panama & 146 & 45 & 51.4 & 89.2 & 6784 & 2733 & 1996 & -6.91 & -4.28 & 7.36 & 9.28 \\
\hline Peru & 295 & 522 & 82.4 & 498 & 48420 & 2394 & 1991 & -2.01 & 0.26 & -1.63 & -19.62 \\
\hline Poland & 190 & 216 & 318 & 1870 & 105900 & 2800 & 1990 & -25.60 & -5.65 & 12.15 & -1.09 \\
\hline Portugal & 241 & 488 & 322 & 725 & 77670 & 7799 & 1983 & -5.07 & -2.52 & 4.26 & 0.88 \\
\hline Romania & 17 & 656 & 145 & 716 & 30250 & 1320 & 1991 & -64.40 & -18.42 & 43.11 & 18.83 \\
\hline Singapore & 406 & 156 & 2120 & 1430 & 54550 & 19848 & No Law & -3.31 & -3.00 & 6.67 & 5.01 \\
\hline Spain & 386 & 5380 & 1800 & 6900 & 477000 & 12340 & 1963 & -6.62 & -3.14 & 6.12 & 3.96 \\
\hline Sri Lanka & 253 & 294 & 93.9 & 99.9 & 10030 & 593 & 1987 & -2.01 & -2.34 & 13.07 & -0.17 \\
\hline Sweden & 168 & 383 & 953 & 2530 & 197400 & 23641 & 1953 & 0.32 & -1.30 & 0.68 & 0.82 \\
\hline Thalland & 77 & 537 & 1430 & 3570 & 128900 & 2258 & 1979 & 0.50 & -5.42 & 38.78 & -13.69 \\
\hline Turkey & 196 & 274 & 608 & 2610 & 148500 & 2607 & 1994 & -22.39 & -6.75 & 30.18 & 6.09 \\
\hline United Kingdom & 417 & 5026 & 5740 & 16900 & 969600 & 16881 & 1948 & -1.79 & -2.13 & 0.98 & 0.62 \\
\hline United States & 84 & 13952 & 12400 & 88100 & 5716000 & 23456 & 1890 & 2.14 & -0.68 & 1.16 & -0.15 \\
\hline Venezuela & 416 & 360 & 303 & 1030 & 66710 & 3508 & 1991 & -1.59 & -1.01 & 3.98 & -1.34 \\
\hline Average & 11484 & 1502 & 1419 & 6414 & 406973 & 10520 & 1970 & -7.33 & -3.76 & 10.00 & 2.25 \\
\hline
\end{tabular}


Table 2: Data at a Glance by Industry, 1981-1998

\begin{tabular}{|c|c|c|c|c|c|c|c|c|c|}
\hline \multirow{2}{*}{$\begin{array}{c}\text { ISIC } \\
\text { Industry }\end{array}$} & \multirow[b]{2}{*}{ Description } & \multicolumn{2}{|c|}{ Numbers of } & \multicolumn{2}{|c|}{ Value in Million of US\$ } & \multicolumn{4}{|c|}{ Growth Rates (\%) of } \\
\hline & & Sample ${ }^{1}$ & Firms & Imports & $\begin{array}{c}\text { Domestic } \\
\text { Production }\end{array}$ & $\mathbf{Y} / \mathbf{K}$ & $\mathbf{L} / \mathbf{K}$ & $\mathbf{K}$ & I \\
\hline 311 & Food & 455 & 5244 & 2660 & 18800 & -1.39 & -1.53 & 6.16 & 2.61 \\
\hline 313 & Beverages & 417 & 508 & 307 & 3700 & -3.24 & -1.67 & 6.86 & 0.87 \\
\hline 314 & Tobacco & 402 & 383 & 222 & 1850 & -2.47 & -1.67 & 7.47 & 1.29 \\
\hline 321 & Textıles & 455 & 3414 & 1970 & 6620 & -3.32 & -2.30 & 2.98 & -1.85 \\
\hline 322 & Apparel' & 442 & 2702 & 1150 & 3030 & -3.32 & -2.81 & 7.01 & 2.36 \\
\hline 323 & Leather products & 405 & 441 & 503 & 702 & -3.53 & -2.41 & 3.28 & -2.18 \\
\hline 324 & Footwear & 422 & 426 & 318 & 798 & -5.73 & -3.93 & 5.70 & -2.61 \\
\hline 331 & Wood products & 426 & 2826 & 696 & 3180 & -3.22 & -1.99 & 4.43 & -1.93 \\
\hline 332 & Furniture & 427 & 1655 & 254 & 1980 & -3.17 & -2.38 & 6.53 & 1.99 \\
\hline 341 & Paper and products & 453 & 892 & 974 & 5480 & -4.17 & -2.52 & 6.66 & -0.28 \\
\hline 342 & Prnting and publishing & 450 & 3337 & 249 & 6650 & -4.49 & -3.39 & 9.07 & 5.37 \\
\hline 351 & Industral chemicals & 394 & 414 & 2960 & 8580 & -1.16 & -1.47 & 5.20 & 0.05 \\
\hline 352 & Other chemicals & 405 & 829 & 1340 & 7560 & -3.05 & -2.36 & 8.63 & 4.62 \\
\hline 353 & Petroleum refinenties & 311 & 33 & 1400 & 9020 & -6.31 & -2.35 & 7.88 & -1.31 \\
\hline 354 & Petroleum and coal products & $\cdot 238$ & 174 & 112 & 1090 & -5.11 & -2.45 & 8.26 & 2.26 \\
\hline 355 & Rubber products & 435 & 412 & 308 & 1890 & -4.02 & -2.54 & 5.13 & 2.29 \\
\hline 356 & Plastic products & 437 & 1763 & 774 & 5050 & -4.02 & -2.30 & 9.34 & 5.31 \\
\hline 361 & Pottery and earthenware & 356 & 346 & 82.4 & 550 & -5.28 & -3.98 & 6.91 & -1.20 \\
\hline 362 & Glass and products & 376 & 233 & 223 & 1240 & -5.95 & -3.71 & 8.55 & 0.74 \\
\hline 369 & Non-metallic mineral products & 411 & 1935 & 241 & 4650 & -3.77 & -2.21 & 7.20 & 2.63 \\
\hline 371 & Iron and steel & 374 & 764 & 1360 & 9870 & -3.51 & -2.59 & 3.55 & -2.02 \\
\hline 372 & Non-ferrous metals & 371 & 425 & 1280 & 3940 & -3.14 & -2.13 & 5.43 & 2.03 \\
\hline 381 . & Fabricated metal products & 451 & 4757 & 1380 & 9280 & -3.68 & -2.46 & 6.42 & 1.02 \\
\hline 382 & Machınery except electrical & 418 & 4903 & 5640 & 19100 & -1.97 & -2.39 & 7.51 & 1.08 \\
\hline 383 & Electrical machinery & 451 & 2415 & 5340 & 18500 & -3.81 & -2.75 & 7.20 & 3.59 \\
\hline 384 & Transport equipment & 451 & 1374 & 4660 & 20500 & -3.25 & -3.53 & 6.82 & 3.27 \\
\hline 385 & Scientific equipment & 411 & 707 & 1650 & 2820 & -3.96 & -3.00 & 8.90 & 3.02 \\
\hline 390 & Other manufactured products & 440 & 1530 & 1220 & 2100 & -5.33 & -3.31 & 7.98 & 2.28 \\
\hline
\end{tabular}

Notes: 'Denotes the total number of observations in each industry.

Unless otherwise stated all numbers denote simple averages across countries and years of each industry 
Table 3: Regression Results

\begin{tabular}{|c|c|c|c|c|c|c|}
\hline \multirow[b]{2}{*}{ Explanatory Variables (in log) } & \multirow{2}{*}{$\begin{array}{l}\text { OLS } \\
\text { (1) }\end{array}$} & \multirow{2}{*}{$\begin{array}{c}\text { OLS } \\
(2)\end{array}$} & \multicolumn{2}{|c|}{ 3SLS } & \multicolumn{2}{|c|}{ 3SLS } \\
\hline & & & (3) & $\left(3^{\prime}\right)$ & (4) & $\left(4^{\prime}\right)$ \\
\hline \multirow[t]{2}{*}{ Competstion law } & & 0.420 & & & -0.146 & \\
\hline & & $(0.244)$ & & & $(0.201)$ & \\
\hline \multirow[t]{2}{*}{ Imports } & $-0.223^{+4}$ & $-0.232^{* 4}$ & $-0.139 \approx$ & & $-0.136^{\circ+4}$ & \\
\hline & $(0.107)$ & $(0.107)$ & $(0064)$ & & $(0.064)$ & \\
\hline \multirow[t]{2}{*}{ Imports squared } & -0.002 & -0.002 & & & & \\
\hline & $(0.009)$ & $(0.009)$ & & & & \\
\hline \multirow[t]{2}{*}{ Firms } & 0.372 & 0370 & $-0.138 \div 4$ & $-0.544^{* 4 \%}$ & $-0140^{+\infty}$ & $-0543^{\circ 000}$ \\
\hline & $(0.213)$ & $(0213)$ & $(0052)$ & $(0.149)$ & $(0.052)$ & (0.149) \\
\hline \multirow[t]{2}{*}{ Firms squared } & -0.025 & .0 .025 & $0006^{\not 00}$ & $0.159^{2040}$ & $0.006^{\circ 8 *}$ & 0.15900 \\
\hline & $(0.018)$ & $(0.018)$ & $(0002)$ & $(0.032)$ & $(0.002)$ & $(0.032)$ \\
\hline \multirow[t]{2}{*}{ Firms Imports } & 0.030 & 0.032 & & & & \\
\hline & $(0.018)$ & $(0.018)$ & & & & \\
\hline \multirow[t]{2}{*}{ Sales } & $-1.056^{* 4}$ & $-1.133^{+\infty}$ & $2304^{\infty 00}$ & $-2692^{206}$ & $2320^{2000}$ & -2.692 \\
\hline & $(0.486)$ & $(0.482)$ & $(0.657)$ & $(0.341)$ & $(0.657)$ & $(0.341)$ \\
\hline \multirow[t]{2}{*}{ Sales squared } & 0.024 & $0026^{64}$ & $-0.076^{4 \#}$ & $0.051^{\prime 4 \phi}$ & $-0.077 \approx$ & $0051^{400}$ \\
\hline & $(0.013)$ & $(0.013)$ & $(0.018)$ & $(0010)$ & $(0.018)$ & $(0.010)$ \\
\hline \multirow[t]{2}{*}{ Labor cost } & -0.258 & -0597 & $-3375^{\circ 00}$ & 0427 & -3.458 & 0428 \\
\hline & $(0.959)$ & $(0.983)$ & $(0.999)$ & $(0.418)$ & $(1.006)$ & $(0.418)$ \\
\hline \multirow[t]{2}{*}{ Labor cost squared } & 0.015 & 0.034 & 0.199 & $-0.046^{*}$ & $0205^{+00}$ & $-0.046^{\circ}$ \\
\hline & $(0058)$ & $(0.060)$ & $(0.056)$ & $(0.025)$ & $(0.057)$ & $(0.025)$ \\
\hline \multirow[t]{2}{*}{ GDP } & $3054^{* 0}$ & $3.790^{* 0}$ & & -2939 & & $-2.940^{\text {ats }}$ \\
\hline & $\left(\begin{array}{ll}1 & 051\end{array}\right)$ & $(1.496)$ & & $(0.610)$ & & $(0.610)$ \\
\hline \multirow[t]{2}{*}{ GDPPC } & -1.298 & -1878 & & $4.142^{500}$ & & $4.142^{\circ 04}$ \\
\hline & (1 504) & $(1.502)$ & & $(0.552)$ & & $(0.552)$ \\
\hline \multirow[t]{2}{*}{ Constant } & $-54.393^{\circ 0}$ & $-66.330^{\circ 0}$ & -1.126 & $71319^{\circ 000}$ & -0.950 & $71.342^{\circ 000}$ \\
\hline & $(27.209)$ & $(26.882)$ & $(7.185)$ & $(12.344)$ & $(7.188)$ & $(12.344)$ \\
\hline \multicolumn{2}{|l|}{ Factor shares } & & & Yes & & Yes \\
\hline Industry Fixed Effects & Yes & Yes & Yes & Yes & Yes & Yes \\
\hline Year Fixed Effects & Yes & Yes & Yes & Yes & Yes & Yes \\
\hline Country Fixed Effects & Yes & Yes & Yes & Yes & Yes & Yes \\
\hline Polynomial $(\mathrm{K}, \mathrm{I})$ & Sth order & Sth order & 5 th order & & Sth order & \\
\hline Industry Fixed Effects & Yes & Yes & Yes & & Yes & \\
\hline Year Fixed Effects & Yes & Yes & Yes & & Yes & \\
\hline Country Fixed Effects & Yes & Yes & Yes & & Yes & \\
\hline Sample Size & 10447 & 10447 & 1488 & 1488 & 1488 & 1488 \\
\hline R-squares & 0.4219 & 0.4222 & 0.3499 & 0.9601 & 0.3501 & 0.9601 \\
\hline
\end{tabular}


Table 4: Selection Models

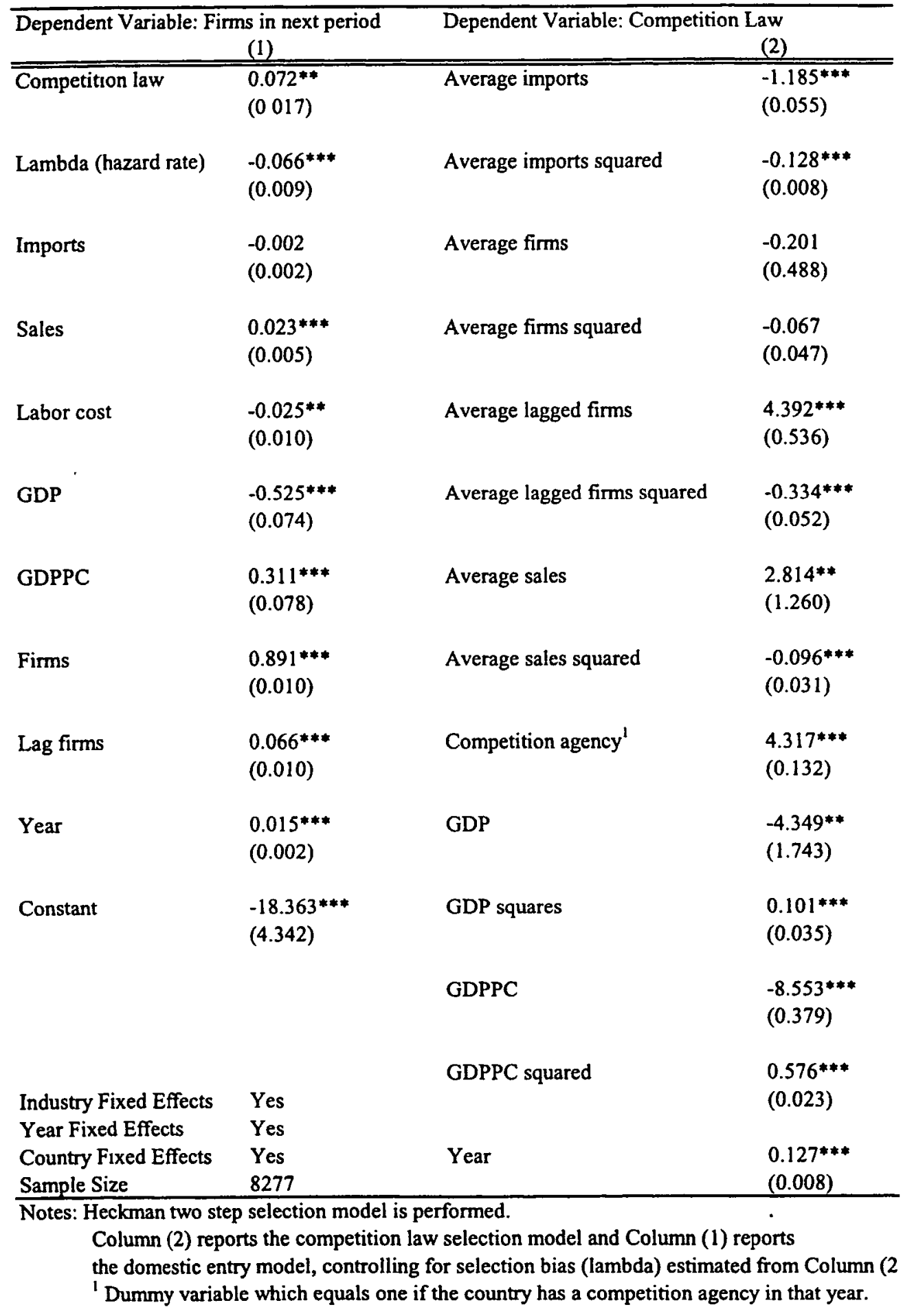


Policy Research Working Paper Series

Title WPS3011 Renegotıation of Concession
Contracts in Latın America

WPS3012 Just-ın-Case Inventories: A CrossCountry Analysıs

WPS3013 Land Sales and Rental Markets in Transition Evidence from Rural Vietnam

WPS3014 Evaluatıon of Financial Liberalızatıon A General Equilibrium Model with Constraıned Occupation Choice

WPS3015 Off and Runnıng? Technology, Trade, and the Risıng Demand for Skilled Workers in Latın Amerıca

WPS3016 Partisan Politics and Intergovernmental Transfers in India

WPS3017 Why is Unemployment so High in Bulgaria?

WPS3018 Integratıng the Least Developed Countries into the World Trading System The Current impact of EU Preferences under Everythıng but Arms

WPS3019 Foreıgn Aıd, Conditınality, and Ghost Thılak Ranaweera of the Financing Gap A Forgotten Aspect of the Aid Debate

WPS3020 Consumption, Health, Gender, and Poverty

WPS3022 Sending Farmers Back to School. The Impact of Farmer Field Schools in Indonesia

WPS3023 Productivity Growth and Product Variety Gaıns from Imitation and Education

WPS3024 R\&D and Development

WPS3025 Trade Structure and Growth

WPS3026 Strategic Approaches to Science and Technology in Development

Anne Case
Angus Deaton
Elızabeth Currie
Jean-Jacques Dethier
Erıko Togo

Gershon Feder

Rınku Murgaı

Jaıme B Quizon

Author

Contact

J LuIs Guasch

Jean-Jacques Laffont

Stéphane Straub

J LuIs Guasch

Klaus Deinınger

Songqing Jin

Xavier Gıné

Robert M Townsend

Carolına Sánch
Norbert Schady

Stutı Khemanı

Jan Rutkowskı

April 2003

Aprıl 2003

April 2003

April 2003

Douglas M Addison

Danıel Lederman Willıam F Maloney

Daniel Lederman Willam F Maloney

Robert Watson

Michael Crawford

Sara Farley
Date

April 2003

April 2003

for paper

$\checkmark$ Troncoso

37826

$\mathrm{J}$ Troncoso

37826

M Fernandez 33766

K. Labrie 31001

H Sladovich 37698

H Sladovich 37698

J Rutkowskı 84569

L Tabada 36896

P Rathan Raj 33705

D Ballantyne 87198

M Rosenquist 82602

April 2003

P Kokıla 33716

April 2003

D Addison 31188

April 2003

P Soto

37892

April 2003

$P$ Soto

37892

April 2003

$R$ Watson 36965 
Policy Research Working Paper Series

\begin{tabular}{|c|c|c|c|c|}
\hline & Title & Author & Date & $\begin{array}{l}\text { Contact } \\
\text { for paper }\end{array}$ \\
\hline WPS3027 & $\begin{array}{l}\text { Financial Intermediation and Growth: } \\
\text { Chinese Style }\end{array}$ & $\begin{array}{l}\text { Genevieve Boyreau- } \\
\text { Debray }\end{array}$ & April 2003 & $\begin{array}{l}\text { P. Sintim-Aboagye } \\
38526\end{array}$ \\
\hline WPS3028 & $\begin{array}{l}\text { Does a Country Need a Promotion } \\
\text { Agency to Attract Foreign Direct } \\
\text { Investment? A Small Analytical Model } \\
\text { Applied to } 58 \text { Countries }\end{array}$ & Jacques Morısset & April 2003 & $\begin{array}{l}\text { M. Feghali } \\
36177\end{array}$ \\
\hline WPS3029 & $\begin{array}{l}\text { Who Benefits and How Much? How } \\
\text { Gender Affects Welfare Impacts of a } \\
\text { Booming Textile Industry }\end{array}$ & $\begin{array}{l}\text { Alessandro Nicita } \\
\text { Susan Razzaz }\end{array}$ & April 2003 & $\begin{array}{l}\text { P. Flewitt } \\
32724\end{array}$ \\
\hline WPS3030 & $\begin{array}{l}\text { The Impact of Bank Regulations, } \\
\text { Concentration, and Institutions on } \\
\text { Bank Margıns }\end{array}$ & $\begin{array}{l}\text { Asl1 Demirgüç-Kunt } \\
\text { Luc Laeven } \\
\text { Ross Levine }\end{array}$ & April 2003 & $\begin{array}{l}\text { A Yaptenco } \\
31823\end{array}$ \\
\hline
\end{tabular}

